\title{
Prognostic value of PD-LI overexpression for pancreatic cancer: evidence from a meta-analysis
}

\author{
This article was published in the following Dove Press journal: \\ OncoTargets and Therapy \\ 16 October 2017 \\ Number of times this article has been viewed
}

\author{
Yongxun Zhuan-Sun $1,2, *$ \\ Fengting Huang ${ }^{2,3, *}$ \\ Min Feng ${ }^{4}$ \\ Xinbao Zhao ${ }^{5}$ \\ Wenying Chen ${ }^{3}$ \\ Zhe Zhu ${ }^{6}$ \\ Shineng Zhang ${ }^{2,3}$ \\ 'Department of Respirology, \\ ${ }^{2}$ Guangdong Provincial Key \\ Laboratory of Malignant Tumor \\ Epigenetics and Gene Regulation, \\ ${ }^{3}$ Department of Gastroenterology, \\ ${ }^{4}$ Department of Nephrology, \\ ${ }^{5}$ Department of Ultrasound, Sun Yat- \\ sen Memorial Hospital, Sun Yat-sen \\ University, Guangzhou, Guangdong \\ Province, China; ${ }^{6}$ Department of \\ Medicine, Division of Regenerative \\ Medicine, University of California, San \\ Diego, School of Medicine, La Jolla, \\ CA, USA \\ *These authors contributed equally \\ to this work
}

Correspondence: Shineng Zhang

Department of Gastroenterology and

Guangdong Provincial Key Laboratory

of Malignant Tumor Epigenetics and

Gene Regulation, Sun Yat-sen Memorial

Hospital, Sun Yat-sen University, No 107

Yanjiang West Road, Guangzhou, 510120,

Guangdong Province, China

Tel +862081332598

$\mathrm{Fax}+862081332244$

Email zhangshn@mail.sysu.edu.cn

\begin{abstract}
Programmed death-ligand 1 (PD-L1) is an immune checkpoint that is often activated in cancer and plays a pivotal role in the initiation and progression of cancer. However, the clinicopathologic significance and prognostic value of PD-L1 in pancreatic cancer (PC) remains controversial. In this study, we conducted a meta-analysis to retrospectively evaluate the relationship between PD-L1 and PC. PubMed and other databases were searched for the clinical studies published up to March 21, 2017, to be included in the meta-analysis. Hazard ratios and their 95\% CIs were calculated. Risk ratios (RRs) were extracted to assess the correlations between the clinicopathologic parameters and PD-L1 expression. Ten studies including 1,058 patients were included in the meta-analysis. The pooled results indicated that positive PD-L1 expression was correlated with a poor overall survival outcome in PC patients (hazard ratio $=1.76,95 \% \mathrm{CI}$ : 1.43-2.17, $P<0.00001)$. Interestingly, high PD-L1 expression was correlated with poor pathologic differentiation ( $\mathrm{RR}=1.57,95 \% \mathrm{CI}: 1.25-1.98, P=0.0001)$ and neural invasion $(\mathrm{RR}=1.30$, 95\% CI: 1.03-1.64, $P=0.03$ ). However, there were no significant correlations between PD-L1 expression and other clinicopathologic characteristics. In summary, our meta-analysis implied that PD-L1 could serve as a negative predictor for the overall survival of PC patients, and high expression of PD-L1 was correlated with poor differentiation and neural invasion, indicating that anti-PD-L1 treatments should be evaluated in PC patients, especially in those who exhibit these two characteristics.
\end{abstract}

Keywords: pancreatic cancer, programmed death-ligand 1, prognosis, clinicopathologic characteristics, meta-analysis, immune checkpoint

\section{Introduction}

Pancreatic cancer (PC) is a lethal malignancy with an overall 5-year relative survival rate of 5\%. ${ }^{1}$ In 2015, an estimated 90,100 new patients were diagnosed with PC in China, with an estimated 79,400 deaths occurring as a result of delayed diagnosis and treatment resistance. ${ }^{2}$ At the time of clinical diagnosis, most cancers are either locally advanced or metastatic, and surgical resection is very difficult. ${ }^{3}$ In addition, PC is resistant to radiotherapy and chemotherapy. ${ }^{4}$ One of the reasons that the PC responds poorly to treatment is due to its ability to evade host immune surveillance. ${ }^{5}$ Emerging evidence has shown that the coinhibitory receptors, such as programmed death 1 (PD-1), play a critical role in cancer immunoediting. ${ }^{6}$

Programmed death-ligand 1 (PD-L1 or B7-H1), the major ligand for PD-1, plays a crucial role in PD-1-dependent immune suppression, which is mediated by an antigenspecific T-cell response. ${ }^{7,8} \mathrm{PD}-\mathrm{L} 1$ is expressed on various tumor cells, including PC cells, and immune cells, including activated $\mathrm{CD}^{+}$and $\mathrm{CD}^{+} \mathrm{T}$ cells, dendritic cells, macrophages, and regulatory $\mathrm{T}$ cells. $.^{9-12} \mathrm{PD}-\mathrm{L} 1$ is not highly expressed in normal tissues; however, PD-L1 is upregulated in many tumors to attenuate the antitumor 
immune response via downregulating antitumor T-cell activity or suppressing apoptosis. ${ }^{13}$

Accumulating studies related to tumoral PD-L1 have been performed on malignancies, such as esophageal, liver, colorectal, breast, lung, glioblastoma, and blood cancers. ${ }^{14-18}$ However, the prognostic role of PD-L1 is still debated. Overexpression of PD-L1 indicates a poor outcome in gastric cancer and non-small-cell lung cancer, ${ }^{19,20}$ in contrast, a better prognosis was observed in glioblastoma patients. ${ }^{18}$ The association between aberrant PD-L1 expression and PC survival has also been evaluated. Due to the relatively small sample sizes, it is necessary to evaluate the association between PD-L1 and the prognosis of PC patients using a meta-analysis of a large cohort of up-to-date reports. In this study, we aimed to conduct a meta-analysis to reveal the association between PC and the clinicopathologic significance and prognostic value of PD-L1.

\section{Materials and methods}

\section{Literature search strategy}

A literature search was performed up to March 21, 2017, for published articles using the electronic databases PubMed, Web of Science, Scopus, and the Cochrane Library. We also searched the Chinese databases of Wanfang Data, China National Knowledge Infrastructure (CNKI), and SinoMed. Searches were limited to human studies without language restriction. The following terms and their combinations were searched in the title/abstract field: "programmed cell death-ligand 1", “PD-L1", “CD274”, “B7-H1”, "pancreatic cancer", and "pancreatic adenocarcinoma". We also carried out manual searches of references cited in the retrieved articles and preceding reviews. In addition, we searched meeting abstracts and virtual presentations of the American Society of Clinical Oncology annual meetings and the European Society of Medical Oncology congresses from 2010 to 2017.

\section{Inclusion and exclusion criteria}

Qualified studies meeting the following eligibility criteria were included: 1) the histologic target was PC;2) the association between PD-L1 expression, prognosis, and clinicopathologic features was investigated; 3) the expression of PD-L1 was categorized into high (positive) and low (negative) groups; and 4) relevant information could be acquired from the full-text study. Exclusion criteria included 1) duplicates, ongoing studies, letters, and reviews; 2) studies about PC cell lines, animal experiments, and other types of cancer; 3) studies not about PD-L1; and 4) incomplete data.

\section{Data extraction and outcomes interest}

Data from the included studies were acquired and summarized independently by two reviewers (Yongxun Zhuan-Sun and Fengting Huang). Disagreement was resolved by a discussion among the authors. The following information was extracted from the included studies: first author's name, year of publication, sample size, and survival time.

The primary outcome measure was the relationship between PD-L1 expression and overall survival. The secondary outcomes were the associations between PD-L1 expression and clinicopathologic characteristics.

\section{Quality assessment and statistical analysis}

The quality of trials was evaluated by the Newcastle-Ottawa scale, ${ }^{21}$ which consists of three factors: patient selection, comparability, and assessment of outcome. A score of 0-9 (allocated as stars) was allocated to each study; those that achieved six or more stars were considered to be high quality.

All the meta-analyses were performed by Review Manager 5.3 (Cochrane Collaboration, Oxford, UK). We addressed time-to-event outcomes by pooling hazard ratios (HRs) from Cox proportional hazards models. If the article supplied the HR with a 95\% CI, we used the data. If the study did not supply the HR with a 95\% CI, we calculated the HR and 95\% CI according to KaplanMeier survival curves using Engauge Digitizer version 4.1 (Engauge Digitizer Software). The data were used following the method proposed by Tierney et al. ${ }^{22}$ The generic inversevariance method was performed to summarize the data. Pooled dichotomous data from other secondary outcomes were presented as risk ratios (RRs). Statistical heterogeneity between studies was assessed using chi-square tests with $P<0.10$ as significance, and heterogeneity was quantified using the $I^{2}$ statistic. The random-effects model was used if there was heterogeneity between studies; otherwise, the fixed-effects model was used.

\section{Results}

\section{Characteristics of included studies}

A total of 10 studies including 1,058 PC patients were used in the final analysis. The initially included studies comprised seven from Asia and three from Europe. All of these studies were cohort studies. Eight articles were published in English and two were in Chinese. PD-L1 expression was examined by immunohistochemistry in eight studies, while the other two studies used quantitative reverse transcription polymerase chain reaction. Based on multivariate analysis, four studies ${ }^{23-26}$ provided HRs with $95 \%$ CIs, while another five 
studies ${ }^{27-31}$ provided survival curves with which to calculate HRs with 95\% CIs. However, the remaining one study ${ }^{32}$ provided neither survival curves nor HRs with $95 \%$ CIs and only provided the correlation between clinicopathologic characteristics and PD-L1 expression. Therefore, it was excluded from the overall survival analysis. The characteristics of the included studies are shown in Table 1.

\section{Effect of PD-LI expression on the overall survival of $\mathrm{PC}$ patients}

Nine studies were included. A fixed-effects model was applied in the meta-analysis for the HR, since the heterogeneity analysis showed that there was no significant heterogeneity among the studies $\left(I^{2}=0 \%, P=0.54\right)$. A significant difference was indicated by the pooled HR of $1.76(95 \% \mathrm{CI}$ : $1.43-2.17, P<0.00001)$ between high and low PD-L1 expression groups (Figure 1).

\section{Correlation between PD-LI expression and clinicopathologic characteristics}

The clinicopathologic characteristics analyzed included tumor status, pathologic stage (TNM stage), metastatic status, differentiation, lymph node metastasis, vascular invasion, and neural invasion. Interestingly, high-level PD-L1 expression was correlated with poor differentiation (RR: $1.57,95 \% \mathrm{CI}$ : 1.25-1.98, $P=0.0001$ ) and neural invasion (RR: $1.30,95 \%$ CI: $1.03-1.64, P=0.03)$, whereas other clinicopathologic characteristics were not significantly correlated with PD-L1 expression. The combined RRs for tumor status, pathologic (TNM) stage, metastatic status, lymph node metastasis, and vascular invasion were 1.04 (RR for higher tumor status, 95\% CI: $0.85-1.27, P=0.74$ ), 1.22 (RR for higher pathologic stage, 95\% CI: $0.20-7.64, P=0.83$ ), 1.40 (RR for M1, 95\% CI: $0.88-2.23, P=0.16$ ), 1.09 (RR for lymph node metastasis, 95\% CI: $0.97-1.23, P=0.14$ ), and 0.96 (RR for vascular invasion, $95 \%$ CI: $0.73-1.26, P=0.76$ ), respectively (Table 2 ).

\section{Subgroup analysis}

Subsequently, we carried out a subgroup analysis according to the methods detecting the expression of PD-L1. As shown in Figure 2, a statistical significance of the pooled HR was observed in both the subgroup analyzed by polymerase chain reaction (HR: $2.24,95 \% \mathrm{CI}: 1.53-3.28, P<0.0001$ ) and the subgroup analyzed by immunohistochemistry (HR: 1.59,

Table I Characteristics of included studies

\begin{tabular}{|c|c|c|c|c|c|c|c|c|}
\hline \multirow[t]{2}{*}{ Study } & \multirow[t]{2}{*}{ Region } & \multirow{2}{*}{$\begin{array}{l}\text { Cancer } \\
\text { type }\end{array}$} & \multirow[t]{2}{*}{ Method } & \multirow[t]{2}{*}{ Cutoff } & \multicolumn{2}{|c|}{ No of patients } & \multirow[t]{2}{*}{ Outcome } & \multirow[t]{2}{*}{ Quality score } \\
\hline & & & & & $\begin{array}{l}\text { PD-LI } \\
\text { high }\end{array}$ & $\begin{array}{l}\text { PD-LI } \\
\text { low }\end{array}$ & & \\
\hline $\begin{array}{l}\text { Birnbaum } \\
\text { et al, }{ }^{23} 2016\end{array}$ & France & PC & qRT-PCR & $\begin{array}{l}\text { Mean PD-LI mRNA expression in } \\
\text { normal pancreatic samples }\end{array}$ & 87 & 366 & $\begin{array}{l}\text { OS and pathologic } \\
\text { features }\end{array}$ & $\star \star \star \star \star \star \star ~$ \\
\hline $\begin{array}{l}\text { Chen et al, }{ }^{27} \\
2014\end{array}$ & China & PC & $\mathrm{IHC}$ & $\begin{array}{l}\text { Cases with }>10 \% \text { cells clearly stained } \\
\text { were considered to be positive }\end{array}$ & 24 & 39 & $\begin{array}{l}\text { OS and pathologic } \\
\text { features }\end{array}$ & $\star \star \star \star$ \\
\hline $\begin{array}{l}\text { Chu et al, }{ }^{32} \\
2011\end{array}$ & China & PC & IHC & $\begin{array}{l}\text { Staining score of } \geq 4 \text { was considered to } \\
\text { be positive }\end{array}$ & 37 & 6 & $\begin{array}{l}\text { Pathologic } \\
\text { features }\end{array}$ & $\star \star \star \star$ \\
\hline $\begin{array}{l}\text { Diana et al, }{ }^{24} \\
2016\end{array}$ & UK & PDAC & $\mathrm{IHC}$ & Median score value ${ }^{\mathrm{b}}$ & 41 & 104 & $\begin{array}{l}\text { OS and pathologic } \\
\text { features }\end{array}$ & $\star \star \star \star$ \\
\hline $\begin{array}{l}\text { Liu et al, }{ }^{28} \\
2016\end{array}$ & China & PC & $\mathrm{IHC}$ & $\begin{array}{l}\text { Cases with }>10 \% \text { PD-LI-positive } \\
\text { tumor cells were considered to be } \\
\text { positive }\end{array}$ & 26 & 20 & OS & $\star \star \star$ \\
\hline $\begin{array}{l}\text { Loos et al, }{ }^{29} \\
2008\end{array}$ & Germany & PDAC & qRT-PCR & Median PD-LI mRNA expression level & 20 & 20 & $\begin{array}{l}\text { OS and pathologic } \\
\text { features }\end{array}$ & $\star \star \star$ \\
\hline $\begin{array}{l}\text { Nomi et al, }{ }^{30} \\
2007\end{array}$ & Japan & PC & $\mathrm{IHC}$ & $\begin{array}{l}\text { Specimens with a } \geq 10 \% \text { PD-LI-positive } \\
\text { tumor cells were classified as positive }\end{array}$ & 20 & 31 & $\begin{array}{l}\text { OS and pathologic } \\
\text { features }\end{array}$ & $\star \star \star$ \\
\hline $\begin{array}{l}\text { Wang et al, }{ }^{31} \\
2010\end{array}$ & China & PC & $\mathrm{IHC}$ & $\begin{array}{l}\text { Specimens with }>5 \% \text { cells of the total } \\
\text { tumor area stained positive were } \\
\text { considered to be positive }\end{array}$ & 40 & $4 \mid$ & $\begin{array}{l}\text { OS and pathologic } \\
\text { features }\end{array}$ & $\star \star \star$ \\
\hline $\begin{array}{l}\text { Wang et al, }{ }^{26} \\
2017\end{array}$ & China & PC & $\mathrm{IHC}$ & $\begin{array}{l}\text { Staining score of } \geq 6 \text { was considered to } \\
\text { be high expression }\end{array}$ & 27 & 67 & $\begin{array}{l}\text { OS and pathologic } \\
\text { features }\end{array}$ & 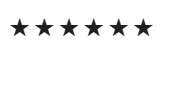 \\
\hline $\begin{array}{l}\text { Yamaki et al, } \\
2017\end{array}$ & Japan & PDAC & $\mathrm{IHC}$ & $\begin{array}{l}\text { The threshold value for judging positive } \\
\text { PID staining of PD-LI was set to } 3.0\end{array}$ & 26 & 16 & $\begin{array}{l}\text { OS and pathologic } \\
\text { features }\end{array}$ & $\star \star \star \star \star$ \\
\hline
\end{tabular}

Notes: aPD-LI staining scores were obtained by multiplying the staining intensities ( 0 , negative; I, weak; 2 , medium; 3 , strong) and the percentage of positive tumor ( 0 , $<5 \%$; I, 5\%-25\%; 2, 26\%-50\%; 3, 5I\%-75\%; 4, >75\%); 'Scoring was based on the proportion of PD-LI-positive tumor cells: I, absent cells, 2 , <25\% cell density, 3, 25\%-50\% cell density, $4,>50 \%$ cell density.

Abbreviations: IHC, immunohistochemistry; OS, overall survival; PC, pancreatic cancer; PDAC, pancreatic ductal adenocarcinoma; PD-LI, programmed death-ligand I; qRT-PCR, quantitative reverse transcription polymerase chain reaction. 


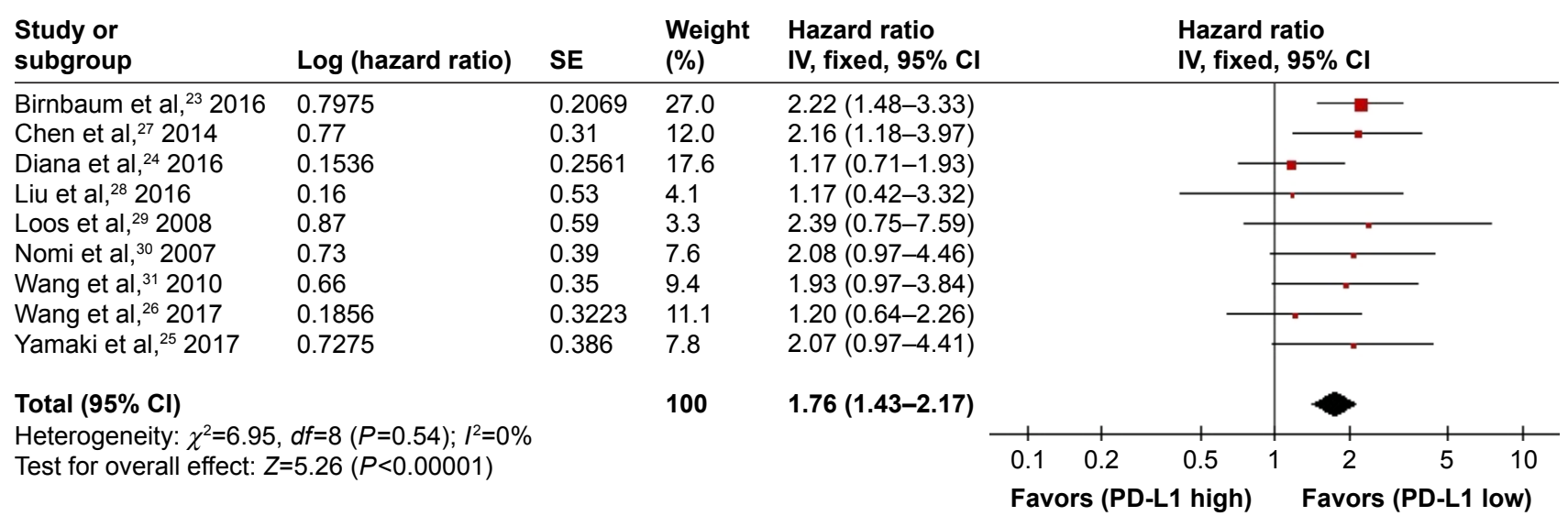

Figure I Forest plot and meta-analysis of the overall survival of the PD-LI high expression group compared with the low expression group. Note: High PD-LI expression was correlated with poorer overall survival in PC patients (HR: I.76, 95\% $\mathrm{Cl}: 1.43-2.17, \mathrm{P}<0.0000 \mathrm{I}$ ).

Abbreviations: $d f$, degrees of freedom; HR, hazard ratio; IV, generic inverse variance method; PC, pancreatic cancer; PD-LI, programmed death-ligand I; SE, standard error.

95\% CI: 1.23-2.04, $P=0.0003$ ) between high and low PD-L1 expression groups. The heterogeneity analysis detected no significant heterogeneity $\left(I^{2}=0 \%, P=0.54\right)$.

\section{Publication bias}

Figure 3 shows a funnel plot of the studies included in this meta-analysis, which illustrates the overall survival. There was no obvious publication bias.

\section{Discussion}

To date, the association between PD-L1 and PC patients remains inconclusive. ${ }^{24,30,33}$ Using meta-analysis, we examined data from a total of 1,058 patients from 10 independent studies. ${ }^{23-32}$ We assessed the clinicopathologic significance and prognostic value of PD-L1 in PC patients. Intriguingly, the pooled results of our analysis showed that positive PD-L1 expression was highly correlated with a poorer overall survival in PC patients. Moreover, high-level PD-L1 expression was correlated with poor differentiation and neural invasion, which is in accordance with a study on lung adenocarcinoma. ${ }^{34}$
However, the analysis found no significant correlations between PD-L1 expression and other clinicopathologic characteristics, including tumor status, pathologic (TNM) stage, metastatic status, lymph node metastasis, and vascular invasion.

Two previous meta-analyses evaluated the relationship of PD-L1 expression and survival in solid tumors and digestive system cancers, both of which included PC patients with a limited number of studies and participants. ${ }^{35,36}$ Our result was comparable to that of Dai et al who analyzed the survival in PC patients. ${ }^{36}$ In addition, our data provided more reliable evidence with more participants and a lower publication bias. Moreover, we analyzed the correlations between PD-L1 expression and other clinicopathologic characteristics, which were not included in the two aforementioned meta-analyses.

Smoking contributes to tumor development and progression in various types of cancer, including lung cancer, oral squamous cell carcinoma, and PC..$^{37-39}$ Smoking cessation is one of the most effective strategies to reduce the risk of tumorigenicity. Interestingly, PD-L1 positivity is associated with smoking history in lung cancer and oral squamous cell

Table 2 Meta-analysis: correlation between PD-LI overexpression and clinicopathologic characteristics

\begin{tabular}{|c|c|c|c|c|c|c|c|c|c|c|}
\hline \multirow{2}{*}{$\begin{array}{l}\text { Outcomes of } \\
\text { interest }\end{array}$} & \multirow{2}{*}{$\begin{array}{l}\text { No of } \\
\text { studies }\end{array}$} & \multicolumn{2}{|c|}{ No of patients } & \multirow[t]{2}{*}{$\mathbf{R R}$} & \multirow{2}{*}{$\begin{array}{l}95 \% \mathrm{Cl} \\
\text { of RR }\end{array}$} & \multirow[t]{2}{*}{$P$-value } & \multicolumn{4}{|c|}{ Study heterogeneity } \\
\hline & & $\begin{array}{l}\text { PD-LI } \\
\text { high }\end{array}$ & $\begin{array}{l}\text { PD-LI } \\
\text { low }\end{array}$ & & & & $\chi^{2}$ & $d f$ & $I^{2}(\%)$ & $P$-value \\
\hline Tumor status & 6 & 188 & 410 & 1.04 & $0.85-1.27$ & 0.74 & 16.1 & 5 & 69 & 0.007 \\
\hline Pathologic stage ${ }^{a}$ & 3 & 97 & 78 & 1.22 & $0.20-7.64$ & 0.83 & 25.3 & 2 & 92 & $<0.00001$ \\
\hline Metastatic status & 4 & 97 & 152 & 1.40 & $0.88-2.23$ & 0.16 & 0.27 & 3 & 0 & 0.97 \\
\hline Differentiation & 6 & 218 & 406 & 1.57 & $1.25-1.98$ & 0.0001 & 7.41 & 5 & 33 & 0.19 \\
\hline Lymph node metastasis & 7 & 224 & 414 & 1.09 & $0.97-1.23$ & 0.14 & 8.52 & 6 & 30 & 0.20 \\
\hline Vascular invasion & 3 & 105 & 176 & 0.96 & $0.73-1.26$ & 0.76 & 1.35 & 2 & 0 & 0.51 \\
\hline Nervous invasion & 4 & 145 & 217 & 1.30 & $1.03-1.64$ & 0.03 & 3.79 & 3 & 21 & 0.29 \\
\hline
\end{tabular}

Notes: ${ }^{\text {a }}$ athologic stage $=$ TNM stage. RR was calculated for TNM stage III-IV.

Abbreviations: $d f$, degrees of freedom; PD-LI, programmed death-ligand I; RR, risk ratio. 


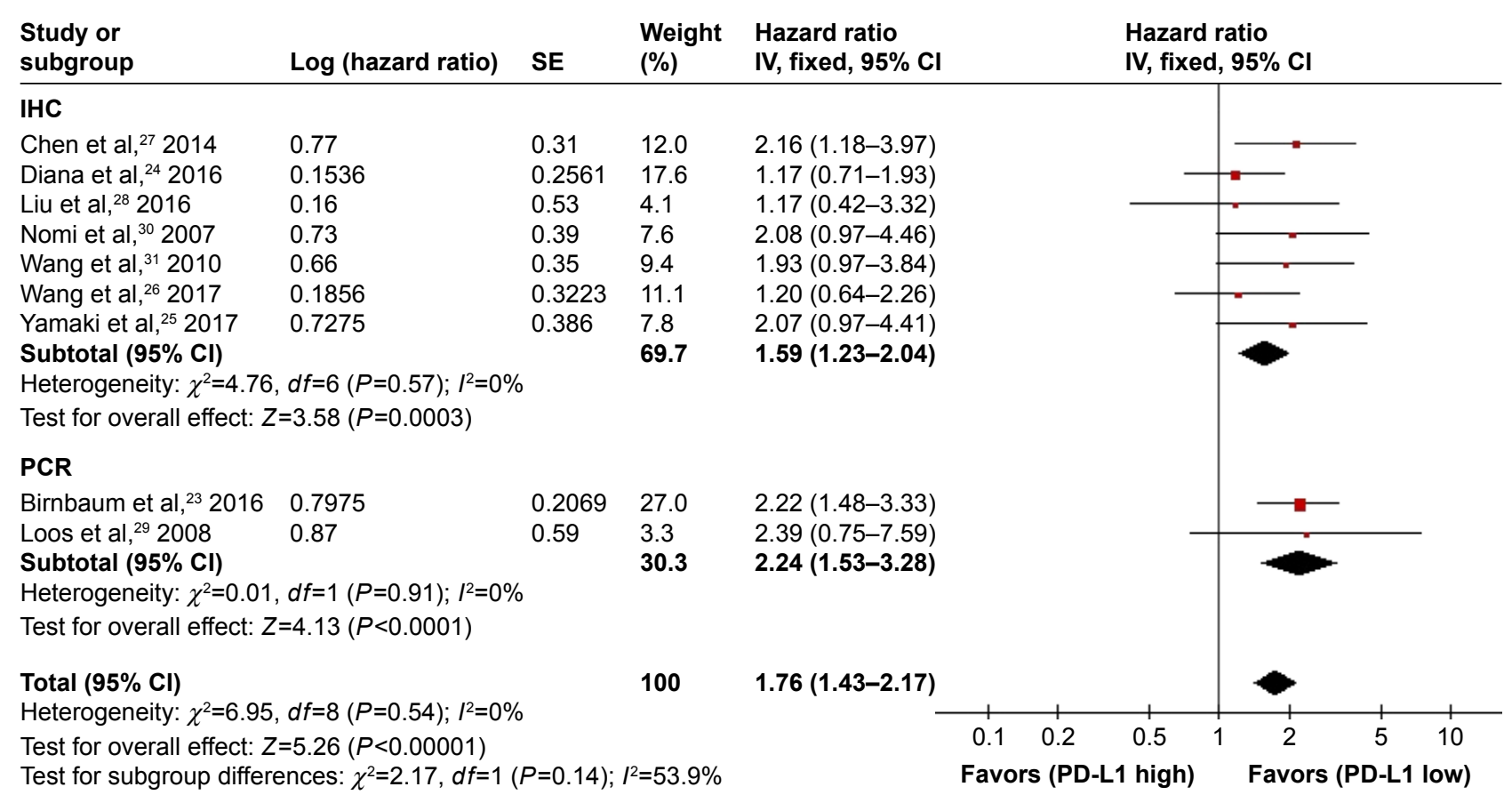

Figure 2 Subgroup analysis based on the methods used to detect PD-LI expression.

Note: A statistical significance of the pooled HR was observed in both the subgroup with PCR method (HR: $2.24,95 \% \mathrm{Cl}: 1.53-3.28, P<0.000 \mathrm{I})$ and the subgroup with IHC method (HR: I.59, 95\% Cl: I.23-2.04, P=0.0003) between high and low PD-LI expression groups.

Abbreviations: $d f$, degrees of freedom; HR, hazard ratio; IHC, immunohistochemistry; IV, generic inverse variance method; PCR, polymerase chain reaction; PD-LI, programmed death-ligand I; SE, standard error.

carcinoma. ${ }^{34,40}$ High PD-L1 expression was a poor prognostic marker in the patients who were smokers, whereas this was not the case in those who never had a smoking habit among lung adenocarcinoma and oral squamous cell carcinoma patients. ${ }^{40,41}$ In addition, it was demonstrated that B7-H3, another member of the B7 family that is also known as an immune modulator, was associated with higher mortality in moderate/heavy smoking patients, but not in nonsmoking/ light smoking patients in a study on lung adenocarcinoma. ${ }^{42}$

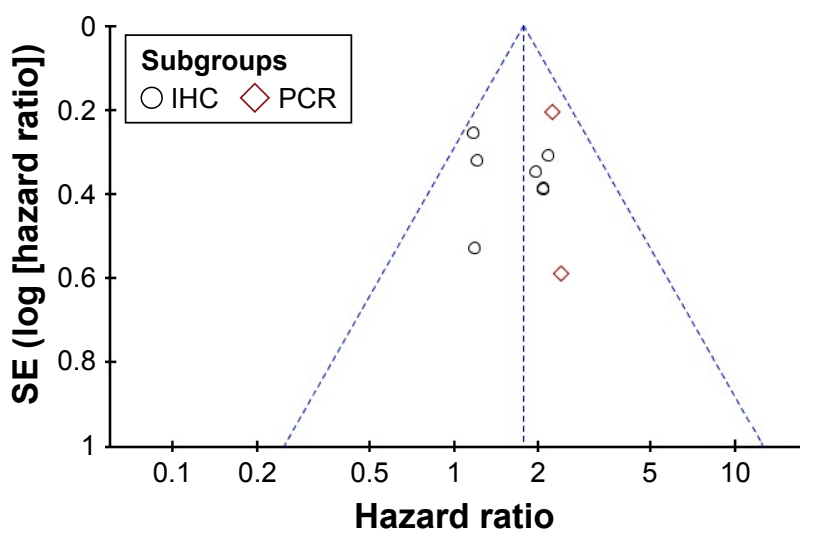

Figure 3 Funnel plot illustrating the meta-analysis of the overall survival. Note: There was no obvious publication bias.

Abbreviations: IHC, immunohistochemistry; PCR, polymerase chain reaction; SE, standard error.
It seemed that the impact of PD-L1 positivity on the survival in PC patients should be evaluated by stratification of smoking status. However, there were no data about the impact of PD-L1 positivity on the survival in PC patients stratified by smoking status in the studies included in this meta-analysis. Further studies are recommended to better interpret the impact of smoking on PD-L1 expression.

The molecular mechanism of overexpressed PD-L1 in PC remains obscure. Upregulation of PD-L1 could be stimulated by cytokines produced by infiltrating immune cells, such as interferon- $\gamma$ (IFN- $\gamma$ ), interleukin (IL)-4, IL-10, vascular endothelial growth factor, and growth cell stem factor, in some solid tumors. ${ }^{43-46}$ In addition, PD-L1 overexpression was observed in acute myeloid leukemia through IFN- $\gamma$ or toll-like receptor stimulation in blast cells from patients via the mitogen-activated protein kinase kinase/extracellular signalrelated kinase pathway and the myeloid primary differentiation response 88/tumor necrosis factor receptor-associated factor 6 pathway. ${ }^{47}$ Moreover, constitutive oncogene pathway activation could also promote PD-L1 expression, for instance, in non-small-cell lung cancer, and specifically, the anaplastic lymphoma kinase/signal transducer and activator of transcription 3, phosphoinositide 3-kinase, and mitogen-activated protein kinase kinase/extracellular signal-related kinase/signal 
transducer and activator of transcription 1 pathways can activate PD-L1 expression. ${ }^{48,49}$ It was reported that the expression of PD-L1 in PC cells was induced via CD8 $8^{+}$T-cell IFN- $\gamma-$ secretion. ${ }^{50,51}$ Therefore, PD-L1 expression might be modulated via different pathways among different tumor types. ${ }^{43,44,49}$

Due to conventional treatment resistance in PC, new immunotherapeutic strategies are urgently needed. ${ }^{52,53}$ Immunotherapy with immune checkpoint inhibition has shown promise as a therapeutic approach. ${ }^{54} \mathrm{PD}-\mathrm{L} 1$, a critical immune checkpoint, is the primary PD-1 ligand, and it can decrease cytokine secretion and attenuate the biologic function of PD- $1+$ cells and tumor-infiltrating $\mathrm{CD}^{+}$and $\mathrm{CD} 8^{+}$ T-cells. ${ }^{55}$ These properties of PD-L1 may allow it to serve as a potentially promising target for cancer immunotherapy. ${ }^{54}$ PD-L1 monoclonal antibodies exhibited an in vivo antitumor effect on murine $\mathrm{PC}$ by increasing $\mathrm{CD}^{+} \mathrm{T}$-cell infiltration and triggering local immune function. ${ }^{56}$ Furthermore, an effective outcome on murine PC was observed with the combined treatment of an anti-PD-L1 monoclonal antibody and gemcitabine. In addition, several clinical trials using an anti-PD-L1 monoclonal antibody, such as durvalumab and BMS-936559, were carried out and exhibited an appealing effect. ${ }^{57}$

High-level PD-L1 expression was correlated with a poorer overall survival in PC patients in our meta-analysis, which suggested that an anti-PD-L1 monoclonal antibody may be a new, promising treatment strategy for PC patients. Additional clinical trials are needed to evaluate the efficacy and safety of anti-PD-L1 monoclonal antibodies in patients with PC. The positive correlations between high-level PD-L1 expression and poor differentiation and $\mathrm{PC}$ neural invasion may provide an additional indication for the application of anti-PD-L1 treatment strategies for PC patients with poorly differentiated $\mathrm{PC}$ and neural invasion.

Despite the promising result from this meta-analysis, there are several limitations that need to be further addressed. First, the number of studies in this meta-analysis was moderate with limited statistical power. Second, some studies were not included due to a lack of data about the association between PD-L1 expression and clinicopathologic characteristics. ${ }^{50,58}$ Moreover, studies included in this meta-analysis were mostly single-center retrospective studies and did not include multicenter prospective cohort studies..$^{23,29,30}$ Finally, meta-analysis is a retrospective method that is subject to methodological limitations. Therefore, further studies are recommended to better interpret the available datasets.

\section{Conclusion}

Our meta-analysis implied that PD-L1 may act as a negative predictor for the overall survival of PC patients, and high expression of PD-L1 was correlated with poor differentiation and neural invasion. However, further studies are recommended to better interpret the available datasets.

\section{Acknowledgments}

This work was supported by grants from the National Natural Science Foundation of China (No 81572348 and No 81602123), the Science and Technology Planning Project of Guangdong Province (No 2014A020212386), the Guangdong Province Natural Science Foundation (No 2015A030313115 and No 2016A030313363), and the Foundation of Guangzhou Science and Technology Bureau (No 201510010206).

\section{Disclosure}

The authors report no conflicts of interest in this work.

\section{References}

1. Siegel RL, Miller KD, Jemal A. Cancer statistics, 2015. CA Cancer J Clin. 2015;65(1):5-29.

2. Chen W, Zheng R, Baade PD, et al. Cancer statistics in China, 2015. CA Cancer J Clin. 2016;66(2):115-132.

3. Zhou B, Zhan H, Tin L, et al. TUFT1 regulates metastasis of pancreatic cancer through HIF1-Snail pathway induced epithelial-mesenchymal transition. Cancer Lett. 2016;382(1):11-20.

4. Kadera BE, Toste PA, Wu N, et al. Low expression of the E3 ubiquitin ligase CBL confers chemoresistance in human pancreatic cancer and is targeted by epidermal growth factor receptor inhibition. Clin Cancer Res. 2015;21(1):157-165

5. Delitto D, Perez C, Han S, et al. Downstream mediators of the intratumoral interferon response suppress antitumor immunity, induce gemcitabine resistance and associate with poor survival in human pancreatic cancer. Cancer Immunol Immunother. 2015;64(12):1553-1563.

6. Xiao G, Deng A, Liu H, Ge G, Liu X. Activator protein 1 suppresses antitumor T-cell function via the induction of programmed death 1. Proc Natl Acad Sci U S A. 2012;109(38):15419-15424.

7. Tassi E, Grazia G, Vegetti C, et al. Early effector T lymphocytes coexpress multiple inhibitory receptors in primary non-small cell lung cancer. Cancer Res. 2017;77(4):851-861.

8. Chatterjee J, Dai W, Aziz NHA, et al. Clinical use of programmed cell death-1 and its ligand expression as discriminatory and predictive markers in ovarian cancer. Clin Cancer Res. 2017;3(13):3453-3460.

9. Daley D, Zambirinis CP, Seifert L, et al. Gammadelta T cells support pancreatic oncogenesis by restraining alphabeta $\mathrm{T}$ cell activation. Cell. 2016;166(6):1485-1499.e1415.

10. Iraolagoitia XL, Spallanzani RG, Torres NI, et al. NK cells restrain spontaneous antitumor $\mathrm{CD} 8+\mathrm{T}$ cell priming through $\mathrm{PD}-1 / \mathrm{PD}-\mathrm{L} 1$ interactions with dendritic cells. J Immunol (Baltimore, Md: 1950). 2016; 197(3):953-961.

11. Shaabani N, Duhan V, Khairnar V, et al. CD169+ macrophages regulate PD-L1 expression via type I interferon and thereby prevent severe immunopathology after LCMV infection. Cell Death Dis. 2016; 7(11):e2446.

12. Li Z, Dong P, Ren M, et al. PD-L1 expression is associated with tumor FOXP3(+) regulatory T-cell infiltration of breast cancer and poor prognosis of patient. $J$ Cancer. 2016;7(7):784-793.

13. Hendriks D, He Y, Koopmans I, et al. Programmed death ligand 1 (PD-L1)-targeted TRAIL combines PD-L1-mediated checkpoint inhibition with TRAIL-mediated apoptosis induction. Oncoimmunology. 2016;5(8):e1202390. 
14. Ohigashi Y, Sho M, Yamada Y, et al. Clinical significance of programmed death-1 ligand-1 and programmed death-1 ligand-2 expression in human esophageal cancer. Clin Cancer Res. 2005;11(8):2947-2953.

15. Chen J, Li G, Meng H, et al. Upregulation of B7-H1 expression is associated with macrophage infiltration in hepatocellular carcinomas. Cancer Immunol Immunother. 2012;61(1):101-108.

16. Kim JH, Park HE, Cho NY, Lee HS, Kang GH. Characterisation of PD-L1-positive subsets of microsatellite-unstable colorectal cancers. Br J Cancer. 2016;115(4):490-496.

17. Muenst S, Schaerli AR, Gao F, et al. Expression of programmed death ligand 1 (PD-L1) is associated with poor prognosis in human breast cancer. Breast Cancer Res Treat. 2014;146(1):15-24.

18. Liu Y, Carlsson R, Ambjorn M, et al. PD-L1 expression by neurons nearby tumors indicates better prognosis in glioblastoma patients. J Neurosci. 2013;33(35):14231-14245.

19. Cooper WA, Tran T, Vilain RE, et al. PD-L1 expression is a favorable prognostic factor in early stage non-small cell carcinoma. Lung Cancer (Amsterdam, Netherlands). 2015;89(2):181-188.

20. Boger C, Behrens HM, Mathiak M, Kruger S, Kalthoff H, Rocken C. PD-L1 is an independent prognostic predictor in gastric cancer of Western patients. Oncotarget. 2016;7(17):24269-24283.

21. Wells G, Shea B, O'Connell D, et al. The Newcastle-Ottawa Scale (nos) for assessing the quality of nonrandomised studies in meta-analyses. Ottawa Hospital Research Institute. Available from: http://www.ohri.ca/ programs/clinical_epidemiology/oxford.asp. Accessed March 28, 2017.

22. Tierney JF, Stewart LA, Ghersi D, Burdett S, Sydes MR. Practical methods for incorporating summary time-to-event data into metaanalysis. Trials. 2007;8(1):16.

23. Birnbaum DJ, Finetti P, Lopresti A, et al. Prognostic value of PDL1 expression in pancreatic cancer. Oncotarget. 2016;7(44):71198-71210.

24. Diana A, Wang LM, D'Costa Z, et al. Prognostic value, localization and correlation of PD-1/PD-L1, CD8 and FOXP3 with the desmoplastic stroma in pancreatic ductal adenocarcinoma. Oncotarget. 2016;7(27) 40992-41004.

25. Yamaki S, Yanagimoto H, Tsuta K, Ryota H, Kon M. PD-L1 expression in pancreatic ductal adenocarcinoma is a poor prognostic factor in patients with high CD8+ tumor-infiltrating lymphocytes: highly sensitive detection using phosphor-integrated dot staining. Int J Clin Oncol. 2017;2(4):726-733.

26. Wang Y, Lin J, Cui J, et al. Prognostic value and clinicopathological features of PD-1/PD-L1 expression with mismatch repair status and desmoplastic stroma in Chinese patients with pancreatic cancer. Oncotarget. 2017;8(6):9354-9365.

27. Chen Y, Sun J, Zhao H, et al. The coexpression and clinical significance of costimulatory molecules B7-H1, B7-H3, and B7-H4 in human pancreatic cancer. Onco Targets Ther. 2014;7:1465-1472.

28. Liu JW, Lu Y, Shen GJ, Yao WF, Huang DS. The relationship of B7-H1 with clinicopathologic characteristics and prognosis of pancreatic carcinoma. Chin J Gen Pract. 2016;14(4):571-574.

29. Loos M, Giese NA, Kleeff J, et al. Clinical significance and regulation of the costimulatory molecule B7-H1 in pancreatic cancer. Cancer Lett. 2008;268(1):98-109

30. Nomi T, Sho M, Akahori T, et al. Clinical significance and therapeutic potential of the programmed death-1 ligand/programmed death-1 pathway in human pancreatic cancer. Clin Cancer Res. 2007;13(7): 2151-2157.

31. Wang L, Ma Q, Chen X, Guo K, Li J, Zhang M. Clinical significance of B7-H1 and B7-1 expressions in pancreatic carcinoma. World J Surg. 2010;34(5):1059-1065.

32. Chu DD, Chu ZH, Zhang JL, et al. Clinical significance of PTEN and B7-H1 expressions in pancreatic carcinoma. Chin JExp Surg. 2011;28(5): 723-726.

33. Song X, Liu J, Lu Y, Jin H, Huang D. Overexpression of B7-H1 correlates with malignant cell proliferation in pancreatic cancer. Oncol Rep. 2014; 31(3):1191-1198.

34. Inamura K, Yokouchi Y, Sakakibara R, et al. Relationship of tumor PD-L1 expression with EGFR wild-type status and poor prognosis in lung adenocarcinoma. Jpn J Clin Oncol. 2016;46(10):935-941.
35. Wu P, Wu D, Li L, Chai Y, Huang J. PD-L1 and survival in solid tumors: a meta-analysis. PLoS One. 2015;10(6):e0131403.

36. Dai C, Wang M, Lu J, et al. Prognostic and predictive values of PD-L1 expression in patients with digestive system cancer: a meta-analysis. Onco Targets Ther. 2017;10:3625-3634.

37. Alexandrov LB, Ju YS, Haase K, et al. Mutational signatures associated with tobacco smoking in human cancer. Science (New York, NY). 2016;354(6312):618-622.

38. Maisonneuve P, Lowenfels AB. Risk factors for pancreatic cancer: a summary review of meta-analytical studies. Int J Epidemiol. 2015; 44(1):186-198.

39. Yadav D, Lowenfels AB. The epidemiology of pancreatitis and pancreatic cancer. Gastroenterology. 2013;144(6):1252-1261.

40. Lin YM, Sung WW, Hsieh MJ, et al. High PD-L1 expression correlates with metastasis and poor prognosis in oral squamous cell carcinoma. PLoS One. 2015;10(11):e0142656.

41. Mori S, Motoi N, Ninomiya H, et al. High expression of programmed cell death 1 ligand 1 in lung adenocarcinoma is a poor prognostic factor particularly in smokers and wild-type epidermal growth-factor receptor cases. Pathol Int. 2017;67(1):37-44.

42. Inamura K, Yokouchi Y, Kobayashi M, et al. Tumor B7-H3 (CD276) expression and smoking history in relation to lung adenocarcinoma prognosis. Lung Cancer (Amsterdam, Netherlands). 2017;103:44-51.

43. Abiko K, Matsumura N, Hamanishi J, et al. IFN-gamma from lymphocytes induces PD-L1 expression and promotes progression of ovarian cancer. Br J Cancer. 2015;112(9):1501-1509.

44. Quandt D, Jasinski-Bergner S, Muller U, Schulze B, Seliger B. Synergistic effects of IL-4 and TNFalpha on the induction of B7-H1 in renal cell carcinoma cells inhibiting allogeneic T cell proliferation. J Transl Med. 2014;12(1):151.

45. Rodriguez-Garcia M, Porichis F, de Jong OG, et al. Expression of PD-L1 and PD-L2 on human macrophages is up-regulated by HIV-1 and differentially modulated by IL-10. J Leukoc Biol. 2011;89(4):507-515.

46. Fukuda T, Kamai T, Masuda A, et al. Higher preoperative serum levels of PD-L1 and B7-H4 are associated with invasive and metastatic potential and predictable for poor response to VEGF-targeted therapy and unfavorable prognosis of renal cell carcinoma. Cancer Med. 2016;5(8):1810-1820.

47. Kronig H, Kremmler L, Haller B, et al. Interferon-induced programmed death-ligand 1 (PD-L1/B7-H1) expression increases on human acute myeloid leukemia blast cells during treatment. Eur J Haematol. 2014; 92(3):195-203.

48. Chen N, Fang W, Zhan J, et al. Upregulation of PD-L1 by EGFR activation mediates the immune escape in EGFR-driven NSCLC: implication for optional immune targeted therapy for NSCLC patients with EGFR mutation. J Thorac Oncol. 2015;10(6):910-923.

49. Ota K, Azuma K, Kawahara A, et al. Induction of PD-L1 expression by the EML4-ALK oncoprotein and downstream signaling pathways in nonsmall cell lung cancer. Clin Cancer Res. 2015;21(17):4014-4021.

50. Soares KC, Rucki AA, Wu AA, et al. PD-1/PD-L1 blockade together with vaccine therapy facilitates effector T-cell infiltration into pancreatic tumors. J Immunother (Hagerstown, Md: 1997). 2015;38(1):1-11.

51. Wilke CM, Wei S, Wang L, Kryczek I, Kao J, Zou W. Dual biological effects of the cytokines interleukin-10 and interferon-gamma. Cancer Immunol Immunother. 2011;60(11):1529-1541.

52. Ireland L, Santos A, Ahmed MS, et al. Chemoresistance in pancreatic cancer is driven by stroma-derived insulin-like growth factors. Cancer Res. 2016;76(23):6851-6863.

53. Yang SH, Guo JC, Yeh KH, Tien YW, Cheng AL, Kuo SH. Association of radiotherapy with favorable prognosis in daily clinical practice for treatment of locally advanced and metastatic pancreatic cancer. J Gastroenterol Hepatol. 2016;31(12):2004-2012.

54. Azad A, Yin Lim S, D'Costa Z, et al. PD-L1 blockade enhances response of pancreatic ductal adenocarcinoma to radiotherapy. EMBO Mol Med. 2017;9(2):167-180.

55. Gibson A, Ogese M, Sullivan A, et al. Negative regulation by PD-L1 during drug-specific priming of IL-22-secreting T cells and the influence of PD-1 on effector T cell function. J Immunol (Baltimore, Md: 1950). 2014;192(6):2611-2621. 
56. Mace TA, Shakya R, Pitarresi JR, et al. IL-6 and PD-L1 antibody blockade combination therapy reduces tumour progression in murine models of pancreatic cancer. Gut. Epub 2016 Oct 21.

57. Antonia S, Goldberg SB, Balmanoukian A, et al. Safety and antitumour activity of durvalumab plus tremelimumab in non-small cell lung cancer: a multicentre, phase 1b study. Lancet Oncol. 2016;17(3):299-308.
58. Basso D, Fogar P, Falconi M, et al. Pancreatic tumors and immature immunosuppressive myeloid cells in blood and spleen: role of inhibitory co-stimulatory molecules PDL1 and CTLA4. An in vivo and in vitro study. PLoS One. 2013;8(1):e54824.

\section{Publish your work in this journal}

OncoTargets and Therapy is an international, peer-reviewed, open access journal focusing on the pathological basis of all cancers, potential targets for therapy and treatment protocols employed to improve the management of cancer patients. The journal also focuses on the impact of management programs and new therapeutic agents and protocols on

\section{Dovepress}

patient perspectives such as quality of life, adherence and satisfaction. The manuscript management system is completely online and includes a very quick and fair peer-review system, which is all easy to use. Visit http://www.dovepress.com/testimonials.php to read real quotes from published authors.

\footnotetext{
Submit your manuscript here: http://www.dovepress.com/oncotargets-and-therapy-journal
} 